\title{
INFLUENCE OF MULTIPLE ELECTRON-BEAM REMELTINGS ON THE CHARACTERISTICS OF HVOF AND CGDS SPRAYED CoNiCrAlY COATINGS
}

\author{
VPLIV VEČKRATNEGA PRETALJEVANJA Z ELEKTRONSKIM \\ SNOPOM NA LASTNOSTI S HVOF IN CGDS NAPRŠENIMI \\ CoNiCrAlY PREVLEKAMI
}

\author{
Petra Krajňáková, Larissa Gouvêa, Jan Čupera, Vít Jan, Ivo Dlouhý, Zdeněk Spotz \\ Institute of Materials Science and Engineering, NETME Centre, Brno University of Technology, Faculty of Mechanical Engineering, \\ Technická 2, Brno 616 69, Czech Republic \\ krajnakova@fme.vutbr.cz
}

Prejem rokopisa - received: 2017-06-30; sprejem za objavo - accepted for publication: 2017-12-21

\author{
doi:10.17222/mit.2017.092
}

\begin{abstract}
Nanostructured CoNiCrAlY bond coatings were deposited onto a Ni-based alloy (Inconel 718) by both HVOF and CGDS spraying techniques. Subsequently, the deposits were remelted by an electron beam up to depth of about $100 \mu \mathrm{m}$, which resulted in the removal of defects on the substrate to the bond coat interface. This paper examines the influence of the parameters used for EB remelting, including multiple remelting on the microstructural changes, phase modification and the final state of the coatings. The amount of porosity in the coatings and the surface roughness has been evaluated. Scanning electron microscopy and X-ray diffraction were performed in order to characterize the phase modification before and after the applied treatment. The results indicated that multiple remelting improved the coating in terms of porosity, surface roughness decrease, mechanical strength and chemical homogeneity. This study also demonstrates that the CGDS deposition represents a promising alternative for CoNiCrAlY bond coat manufacturing.

Keywords: bond coat, CoNiCrAlY, cold gas dynamic spraying, HVOF spraying, EB remelting
\end{abstract}

Nanostrukturirane prevleke na osnovi CoNiCrAlY so avtorji prispevka nanesli na podlago iz Ni superzlitine (Inconel 718) z dvema metodama naprševanja; z zelo hitrim naprševanjem kovinskih delcev v toku mešanice plinastega goriva in kisika (HVOF; angl.: High Velocity Oxygen Fuel) in tehniko dinamičnega naprševanja v hladnem plinu (CGDS; Cold Gas Dynamic Spraying). Sledilo je takojšnje pretaljevanje napršenih prevlek z elektronskim snopom do globine približno 100 um, kar naj bi odstranilo napake nastale med naprševanjem in izboljšalo povezavo prevlek s podlago. V članku avtorji opisujejo vpliv parametrov uporabljenega pretaljevanja $\mathrm{z}$ elektronskim snopom, vključno z vplivom večkratnega pretaljevanja na mikrostrukturne spremembe, fazne modifikacije in končno stanje prevlek. Ovrednotili so poroznost izdelanih prevlek in poroznost njihove površine. Izvedli so analize z vrstičnim elektronskim mikroskopom (SEM; angl.: Scanning Electron Microscopy) in rentgensko difrakcijo (angl.: X-Ray Diffraction), da so lahko določili fazne transformacije pred in po obdelavi prevlek. Rezultati preiskav so pokazali, da večkratno pretaljevanje izboljša kakovost prevlek v smislu zmanjšanja njihove poroznosti in površinske hrapavosti, izboljša kemijsko homogenost in trdnost. Študija je prav tako pokazala, da izdelava prevlek na osnovi CoNiCrAlY z CGDS postopkom lahko predstavlja alternativo drugim postopkom naprševanja te vrste prevlek.

Keywords: oplaščenje, CoNiCrAlY prevleke, CGDS - dinamično naprševanje v hladnem plinu, HVOF - zelo hitro naprševanje kovinskih delcev $\mathrm{v}$ toku mešanice goriva in kisika, pretaljevanje $\mathrm{z}$ elektronskim snopom

\section{INTRODUCTION}

Increasing demands for higher gas-turbine engine performance have led to the development of thermal barrier coating (TBC) systems applied to the engine's hot-components. TBCs typically consist of an underlying McrAlY (M=Ni, Co or both) bond coat with yttria partially stabilized zirconia ceramic top coat. Bond coats are typically manufactured using air-plasma spraying (APS), low-pressure plasma spraying (LPPS), high-velocity oxygen fuel spraying (HVOF). ${ }^{1-3}$

In recent years cold gas dynamic spraying (CGDS) has emerged as a promising coating process. CGDS uses kinetic energy rather than thermal energy to produce the coatings. In this process, fine powder particles are accelerated at supersonic speeds and undergo severe plastic deformation upon impacting the substrate to form a coating. ${ }^{4-6}$ This technique has been used to produce coatings from various materials with different microstructures including conventional, polycrystalline, nanocrystalline, amorphous and metastable structures. CGDS operates at much lower temperatures than thermal spray processes, the particles do not get anywhere close to melting temperatures and consequently the achieved coatings exhibit no grain growth. In addition, it can use inert gases that hinder in-process particle surface oxidation. $^{7-10}$ These advantages make CGDS an interesting alternative for the deposition of bond coats. The present study is a part of an ongoing research project that aims to develop high-performance bond coats by means of CGDS for the manufacturing of TBCs to be applied on hot components of gas-turbine engines. The current experimental work uses CGDS and also a conventional 
hot spraying technique (HVOF) to deposit CoNiCrAlY coatings, which are then subsequently remelted by electron beam (EB) to achieve a homogeneous microstructure. The EB remelting process optimisation of CoNiCrAlY coatings is the final objective of the present work.

\section{EXPERIMENTAL PART}

The starting powder was a conventional CoNiCrAlY powder with a spherical morphology and a particle size distribution ranging from $5 \mu \mathrm{m}$ to $20 \mu \mathrm{m}$ with the following composition: Co-36.91, Ni-34.38, Cr-19.35, Al-6.16, Y-0.98, O-0.74 (w/\%). This material is generally used in high-temperature applications such as bond coat where oxidation and hot-corrosion are the key. An Ni- based wrought superalloy - Inconel 718 was used as the substrate. It's chemical composition is Ni-49.84, Fe-19.69, Cr-17.81, Nb-4.6, C-3.03, Mo-2.65, Ti-1, Al-0.73, O-0.64 (w/\%). Two sets of CoNiCrAlY coating (70-75- $\mu \mathrm{m}$ thick) were thermally sprayed onto the Inconel 718 substrates by HVOF and CGDS procedures. EB surface treatment was carried out using K26 15-150 Pro-Beam machine working with maximum beam input power $15 \mathrm{~kW}$ at $150 \mathrm{kV}$ accelerating voltage and $100 \mathrm{~mA}$ current. The EB landing spot was oscillated with $7 \mathrm{~mm}$ amplitude on the specimen surface creating a pattern of overlapping loops. The first set of samples was
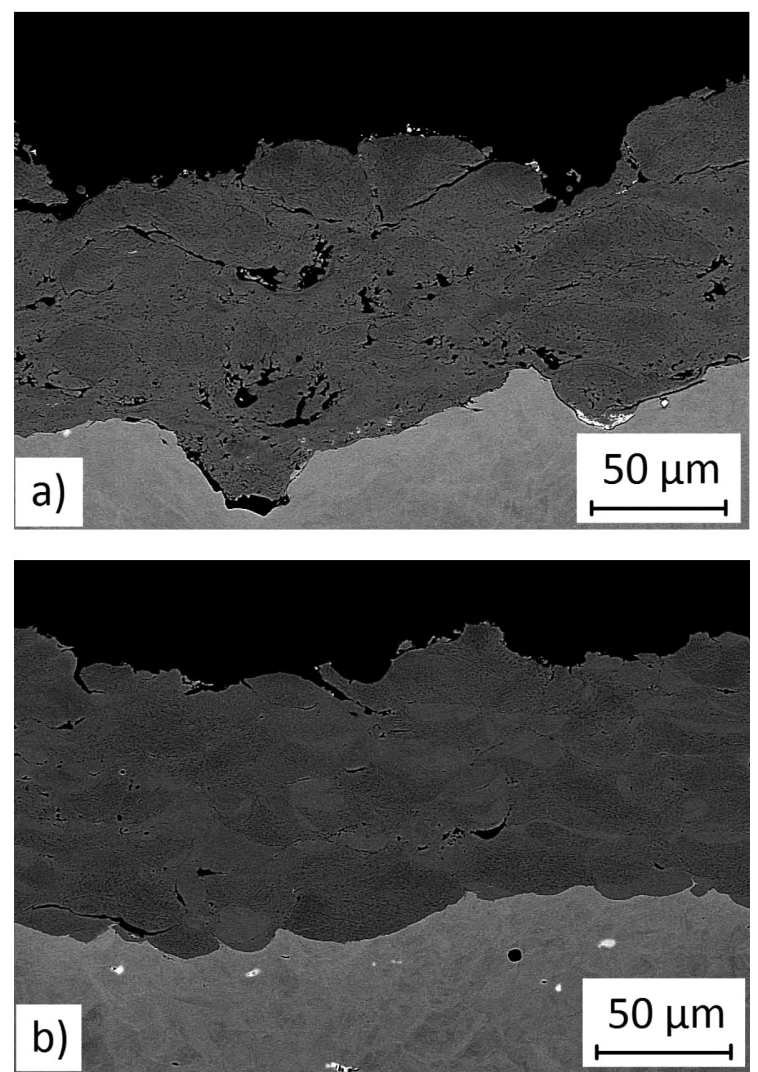

Figure 1: As-deposited CoNiCrAlY coatings applying different deposition techniques: a) HVOF, b) CGDS treated by one cycle of the surface treatment, which consisted of two EB passes. Two consecutive cycles giving four passes altogether were performed in the second set of samples (Table 1). The phase composition before and after EB remelting was measured by X-ray diffraction (XRD) using a Philips X'Pert diffractometer. The diffractometer was set up in Bragg-Brentano geometry using $\mathrm{Cu}-K_{\alpha}$ radiation $(\lambda=0,154 \mathrm{~nm})$ equipped with a linear Xcelerator detector. The surface morphology and metallographic sections of the samples before and after EB treatment were observed by scanning electron microscopy (SEM, Carl Zeiss Ultra Plus).

Table 1: Double $\left(1^{\text {st }}\right.$ set) and two times double remelting ( $2^{\text {nd }}$ set $)$ conditions; $15 \mathrm{~mm} / \mathrm{s}$ processing speed

\begin{tabular}{|c|c|c|l|c|c|c|c|}
\hline \multirow{2}{*}{$\begin{array}{c}\text { EB current } \\
\text { for } 1^{\text {st }} \text { set }\end{array}$} & $\begin{array}{c}\text { I. } \\
(\mathrm{mA})\end{array}$ & $\begin{array}{c}\text { II. } \\
(\mathrm{mA})\end{array}$ & & $\begin{array}{c}\text { I. } \\
(\mathrm{mA})\end{array}$ & $\begin{array}{c}\text { II. } \\
(\mathrm{mA})\end{array}$ & $\begin{array}{c}\text { III. } \\
(\mathrm{mA})\end{array}$ & $\begin{array}{c}\text { IV. } \\
(\mathrm{mA})\end{array}$ \\
\hline sample A & 2.7 & 2.5 & sample C & 2.7 & 2.5 & 2.7 & 2.5 \\
\hline sample B & 3 & 2.7 & sample D & 3 & 2.7 & 3 & 2.7 \\
\hline
\end{tabular}

\section{RESULTS}

Figure 1 shows SEM images of the as-deposited CoNiCrAlY coatings as manufactured by the HVOF and CGDS technique onto an Inconel 718 substrate. The HVOF coating (Figure 1a) shows a number of pores and
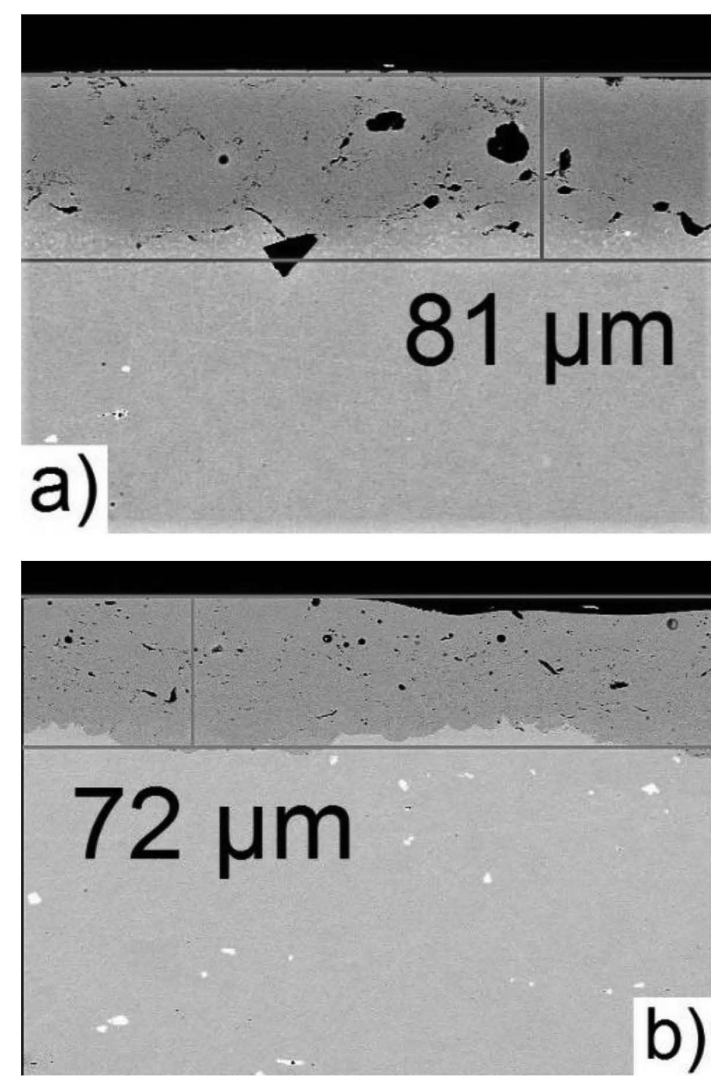

Figure 2: Microstructure of EB remelted bond coats (sample A) deposited by: a) HVOF, b) CGDS 

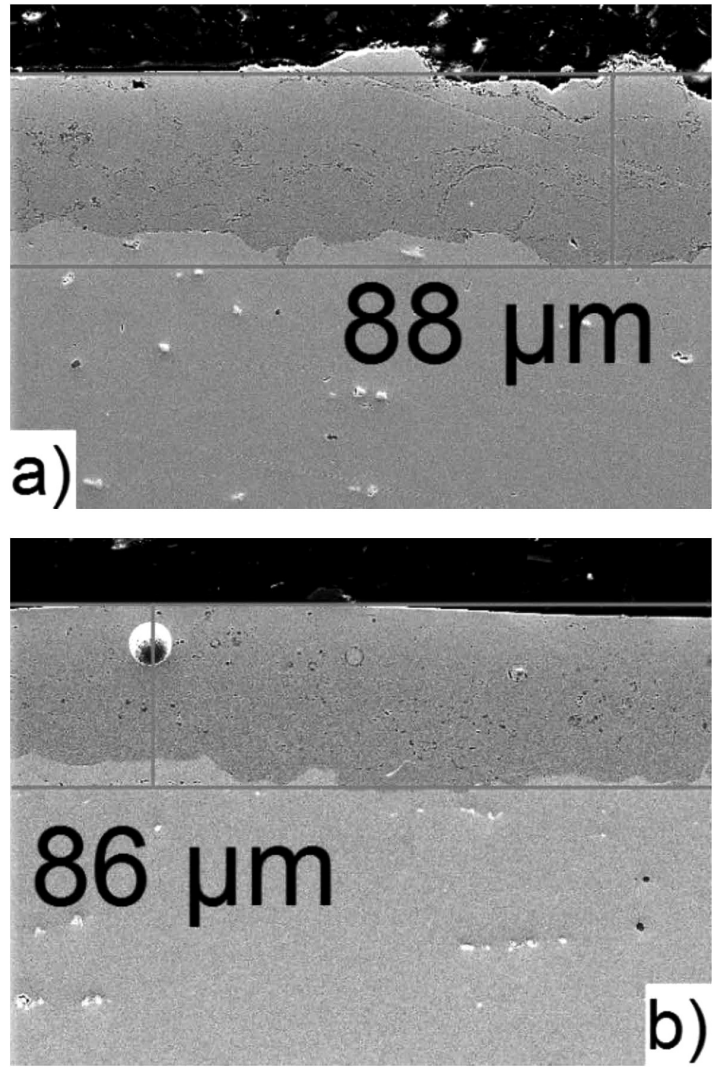

Figure 3: Microstructure of EB remelted bond coats (Sample B) deposited by: a) HVOF, b) CGDS
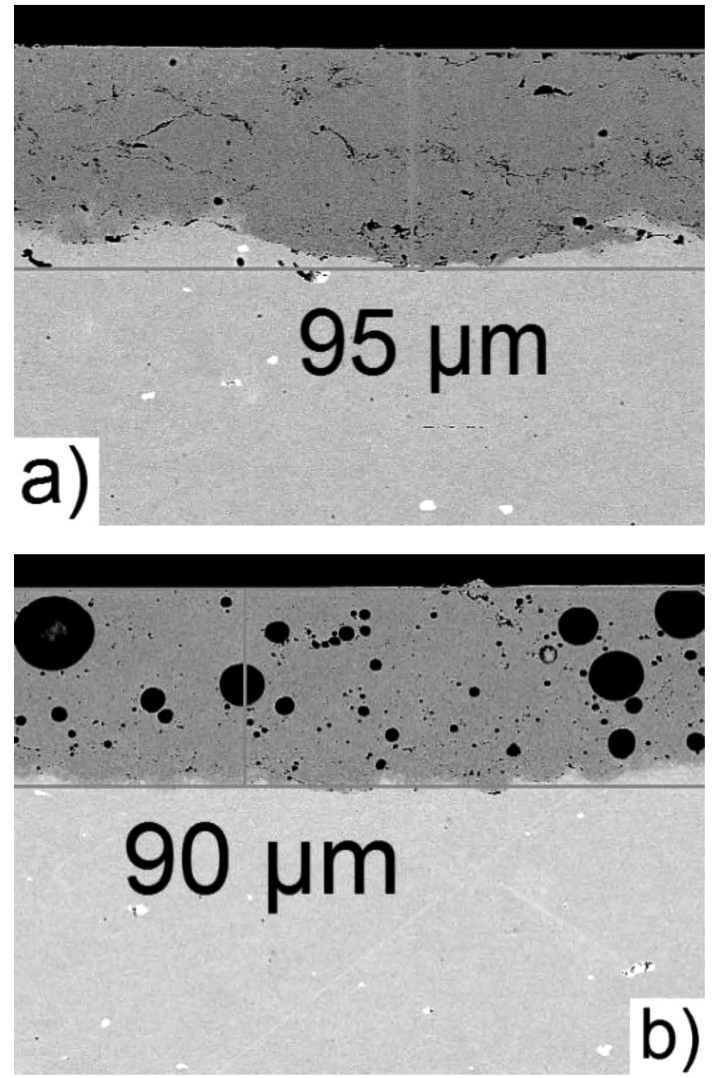

Figure 4: Microstructure of EB remelted bond coats (sample C) deposited by: a) HVOF, b) CGDS locations with poor bonding between splats. The CGDS coating (Figure 1b) exhibits a very limited porosity, negligible number of cracks and also a lower surface roughness. The coatings prepared by both methods (HVOF and CGDS) were EB remelted up to a depth of about $85-100 \mu \mathrm{m}$. After the EB treatment, the coatings were rapidly solidified. Figures $\mathbf{2}$ to $\mathbf{5}$ show SEM microstructure images of the cross-sections after EB treatment according to different EB conditions as shown in Table $\mathbf{1 .}$ Figures $\mathbf{2}$ and $\mathbf{3}$ present microstructures after two EB passes, the processing speed was the same but the beam current changed (Table 1). From Figure 2 can be derived that there still is poor bonding of the coating to the substrate; the depth of the remelted area is too small to heal the interface. Cracks and small pores can be seen in both HVOF and CGDS samples. Original as-deposited porosity and splat boundaries are still visible. An increase of the beam current as applied for sample B (Figure 3) increased the depth layer affected by remelting from $81 \mu \mathrm{m}$ to $88 \mu \mathrm{m}$ for HVOF sample and from $72 \mu \mathrm{m}$ to $86 \mu \mathrm{m}$ for CGDS sample. The cracks and pores counts were reduced significantly; the structure is refined for both treatments. The two times double EB remelting according to $\mathrm{C}$ and $\mathrm{D}$ procedures were performed in order to further increase the depth and to improve the microstructural properties of the remelted layer (Figures 4 and 5). The depth of remelted layer
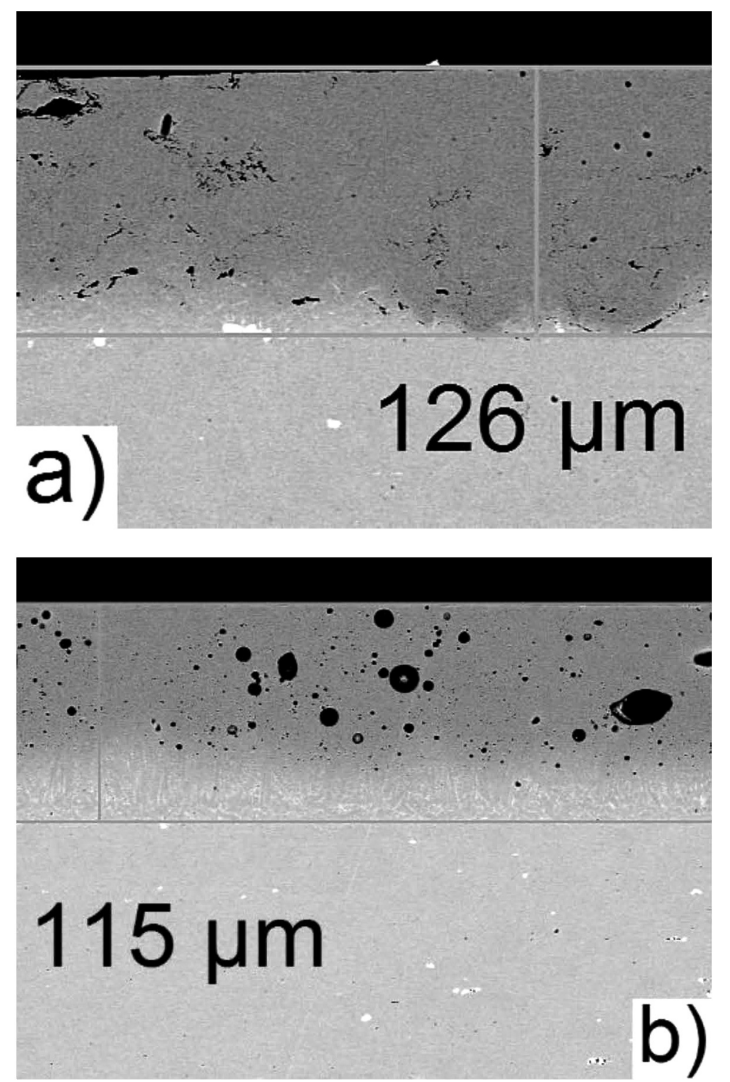

Figure 5: Microstructure of EB remelted bond coats (sample D) deposited by: a) HVOF, b) CGDS 


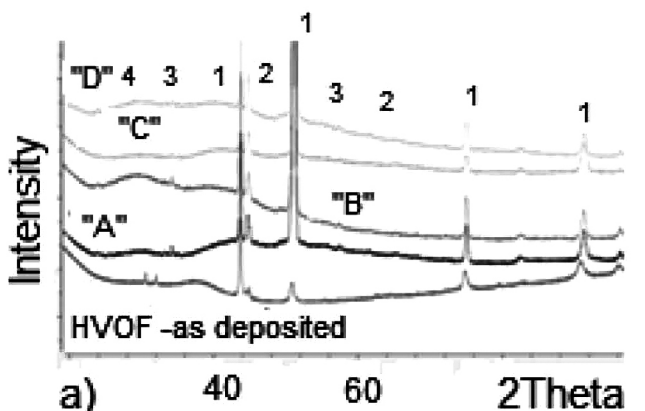

1... Ni
2... Al4Ni3
3... Al2O3
4... AYYO3

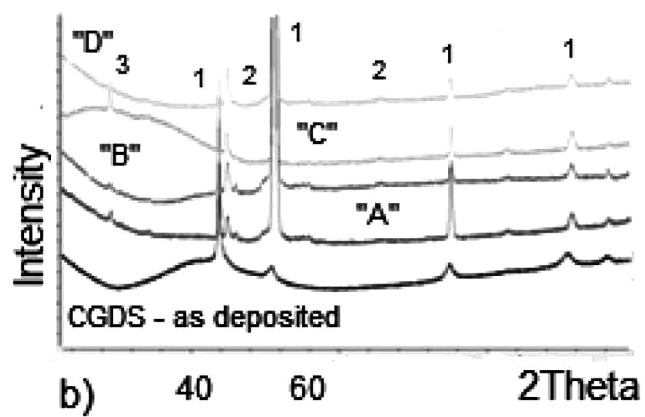

Figure 6: X-ray diffraction patterns of the bond coat deposited by: a) HVOF, b) CGDS technique (before and after EB remelting according to Table 1

after treatment $\mathrm{C}$ reaches $95 \mu \mathrm{m}$ (for $\mathrm{HVOF}$ ) and $90 \mu \mathrm{m}$ (for CGDS), Figure 4, which is not very deep and still some small cracks and pores in HVOF sample and large ones in CGDS sample are observable. For treatment condition "D" similar findings were found as follow from Figure 5. Here some major defects and pores (in CGDS) are newly formed during surface treatment, while smaller ones (were seen in HVOF) sample.

\subsection{X-ray diffraction measurements}

XRD patterns of the CoNiCrAlY coatings by both techniques before and after remelting are presented in Figure 6. Material before the EB-remelting consists of only one FCC phase, that can be identified as Ni-based solid solution (at both HVOF and CGDS).

After EB-remelting of the material new phases like $\mathrm{Al}_{2} \mathrm{O}_{3}, \mathrm{Al}_{4} \mathrm{Ni}_{3}$ (at both HVOF and CGDS) and $\mathrm{AlYO}_{3}$, $\mathrm{Al}_{5} \mathrm{Y}_{3} \mathrm{O}_{12}$ for $\mathrm{HVOF}$ sample appeared. During the EB treatment, although it is done in vacuum, aluminium oxide has formed. This might be due to the reaction of the oxygen that has adsorbed to the individual powder particles and aluminium at high temperatures during EB remelting. The $\mathrm{AlYO}_{3}$ appears in the form of droplets on the modified surface after the EB remelting. These droplets consist mainly of aluminium oxide with a small yttrium-rich grains.?

\section{DISCUSSION}

The influence of the parameters used in electronbeam remelting including the effect of multiple remelt- ing passes on the microstructural changes and state of the coatings have shown the capability of the technique. When comparing the defectness of bond coat and its interface to substrate for HVOF and CGDS this finding appears to be more important for the HVOF and probably also similar high-temperature coating techniques. Mainly the weak interface to substrate appears to be critical issue as shown, e.g., in ${ }^{11}$. According to recent investigations the qualitative improvement of $\mathrm{TBCs}$ function will need to fix several issues but the bond coat to substrate interface belongs to the main challenge. Taking into account thermally grown oxide layer during component/TBC operation this location leads very often to $\mathrm{BC} / \mathrm{TBC}$ delamination and thus loss of the key TBC functions. Prevention to the delamination crack initiation by interface removal as suggested by EB remelting procedure could lead to substantial enhancement of the $\mathrm{BC}$ and TBC functional properties. The potential of a new-generation electron beam technology treatment on the surface and interface modification of CoNiCrAlY bond coats on Inconel substrates was demonstrated. Through the treatment, a good quality transient interface can be obtained for coatings deposited via both the HVOF and CGDS technologies at dissimilar thicknesses. The changes in the microstructure and chemical gradient (from a distinct step into transient) of the interface could prevent the formation of detrimental phases upon subjecting the component to elevated temperatures. Further to that, porosity of the bond coats can be reduced in the treatment and the initial splats structure was not retained, thereby producing bulk-like material. The outcomes can bring partial changes in technology, e.g. a vacuum thermal treatment of the component after the bond coat application could be replaced by electronbeam remelting. Such a procedure will bring improvement of the bond coat to substrate interface resulting in enhancement of $\mathrm{BC}$ adhesion, even when the production costs will be smaller.

\section{CONCLUSIONS}

The results obtained show that the application of the electron-beam surface modification including the bond coat structure and interface to substrate is associated with certain advantages. These are mainly associated with removal of the interface boundary between the bond coat and the substrate and the homogenisation of the bond coat microstructure. In addition, under selected parameters the EB treatment provided a smooth surface and a low porosity level. The technology parameter window for the successful application of EB remelting has been shown to be relatively narrow. The understanding of observed negative phenomena like pores is still limited and needs to be further investigated. 


\section{Acknowledgment}

The works have been supported by the financial support from the project NETME plus centre (Lo1202), project of Ministry of Education, Youth and Sports under the "national sustainability program", also supported by specific research BUT project: FSI-S-17-4708.

\section{REFERENCES}

${ }^{1}$ V. Kumar, K. Balasubramanian, Progress update on fallure mechanism of advanced thermal barrier coatings: A review, Progress in Organic Coatings, 90 (2016), 54-82, doi:10.1016/j.porgcoat.2015. 09.019

${ }^{2}$ J. J. Tang, Y. Bai, J. C. Zhang, K. Liu, X.Y. Liu, P. Zhang, Y. Wang, L. Zhang, G.Y. Liang, Y. Gao, J.F. Yang, Microstructural design and oxidation resistance of CoNiCrAlY alloy coatings in TBC system, J. Alloys Compd., 688 (2016), 729-737, doi:10.1016/j.jallcom.2016. 07018

${ }^{3}$ G. Marginean, D. Utu, Cyclic oxidation behaviour of different treated CoNiCrAlY coatings, Applied Surf. Sci., 258 (2012) 20, 8307-8311, doi:10.1016/j.apsusc.2012.05.050

${ }^{4}$ Y. Ichikawa, K. Ogawa, Critical deposition condition of CoNiCrAlY CS based on particle deformation behaviour, J. Thermal Spray Tech, 340 (2017), 1-10, doi:10.1007/s11666-016-0477-6

${ }^{5}$ A. Khanna, W. Rathod, Development of CoNiCrAlY oxidation resistant hard coatings using HVOF and CS techniques, Int J. Refract Met Hard Mater, 49 (2015), 374-382, doi:10.1016/j.ijrmhm.2014. 08010
${ }^{6}$ H. Chen, Y. Si, D. McCartney, An analytical approach to the B-phase coarsening behaviour in a thermally sprayed CoNiCrAlY bond coat alloy, J. alloys Compd., 704 (2017), 359-341, doi:10.1016/j.jallcom. 2017.02.002

${ }^{7}$ P. Richer, A. Zúniga, M. Yandouzi, B. Jodoin, CoNiCrAlY microstructural changes induced during CGDS, Surf. Coat. Tech., 203 (2008), 364-369, doi:10.1016/j.surfcoat.2008.09.014

${ }^{8}$ J. Čížek, M. Matějková, J. Kouřil, J. Čupera, I. Dlouhý, Potential of New-Generation EB Technology in Interface Modification of Cold and HVOF Sprayed MCrAlY Bond Coats, Adv. Mater. Sci. Eng., (2016), 1-6, doi:10.1155/2016/9070468

${ }^{9}$ D. Utu, G. Marginean, W. Brandl, C. Ioan, Improvement of the oxidation behaviour of EB remelted MCrAlY coatings, Sol. State. Coat., 7 (2005), 461, doi:10.1016/j.solidstatesciences.2005.01.003

${ }^{10}$ R. Raoelison, Ch. Verdi, H. Liao, CGDS additive manufactured today: deposit possibilities, technological solutions and viable applications, Materials and Design, 133 (2017), 266-287, doi:10.1016/ j.matdes.2017.07.067

${ }^{11}$ P. Gavendová, J. Č́́žek, J. Čupera, M. Hasegawa, I. Dlouhý, Microstructure modification of CGDS and HVOF sprayed CoNiCrAlY bond coat remelted by electron beam, Procedia Materials Science, 12 (2016), 89-94, doi:10.1016/j.mspro.2016.03.016 